\title{
IMPACT OF URBANIZATION ON SOCIO ECONOMIC STATUS OF AGING A CASE STUDY OF JORHAT DISTRICT OF ASSAM
}

\author{
Himanshu Gogoi \\ Assistant Teacher, Gangmouthan Govt. Girls MV School, Gangmouthan, Biswanath, Assam,
}

Article DOI: $\underline{\text { https://doi.org/10.36713/epra4778 }}$

\begin{abstract}
Aging population is evolving into a prime concern for developing countries like India as the median age of these countries are increasing with the every passing day. The problem ageing is facing by some developed countries among those japan is mentionable one. As far as concern of India at present it is not a serious current problem nor it need desperate attention. However, with the increasing median age of the population and weakening root of family values bringing a hazy future for those who are to be become aged in coming days. Perhaps it is due to coming up of new working culture which not allows the children to stay with their parents and they remain away from them for a longer period of time for the sake of job. The problem becomes a matter of serious concern when one of the spouses already died and other need social support and the children can't come to their parents even they wanted to do so. To present socio economic status of ageing impacted by urbanization with special reference to jorhat town
\end{abstract}

KEYWORDS - aging, population, urbanization, family value, economic status

\section{I.INTRODUCTION}

In general ageing or old or aged person means the persons who are above 60 year and who are mostly depended on other. If people live longer and have fewer children than before, the population is ageing. As a result, the share of elderly people in the total population rises. The so-called old-age dependency ratio displays collective ageing.

Generally the definition of old age is no general agreement on the age at which a person becomes old. The common use of a calander age to mark the threshold of old age assume equivalent with biological age, yet at the same time, it is generally accepted that these two are not necessarily synonymous., which attention was drawn to older population in many developing countries, the definition of the old age many times followed the same path as that in more developed countries i.e. the govt. set the definition by starting a retirement.

According to Gorman,"The ageing process is of course a biological reality which has its own dynamic, largely beyond human control. However, it is also subject to the constructions by which each society makes sense of old age. In the developed world, chronological time plays a paramount role. The age of 60 or 65 , roughly equivalent to retirement ages in most developed countries, is said to be the beginning of old age. In many parts of the developing world, chronological time has little or no importance in the meaning of old age. Other socially constructed meanings of age are more significant such as the roles assigned to older people; in some cases it is the loss of 


\section{SJIF Impact Factor: 7.001| ISI I.F.Value:1.241| Journal DOI: 10.36713/epra2016 \\ ISSN: 2455-7838(Online) \\ EPRA International Journal of Research and Development (IJRD) \\ Volume: 5 | Issue: 7 | July 2020 \\ - Peer Reviewed Journal}

roles accompanying physical decline which is significant in defining old age. Thus, in contrast to the chronological milestones which mark life stages in the developed world, old age in many developing countries is seen to begin at the point when active contribution is no longer possible." (2000)[1]

Aging population is evolving into a prime concern for developing countries like India as the median age of these countries are increasing with the every passing day. The problem ageing is facing by some developed countries among those Japan, German is mentionable one .For example, Today, the German old-age dependency ratio 65 (people older than 65 years per 100 persons aged 15 to 64 ) is 26.5 and will rise up to 39.3 in 2025 and 55.8 in 2050.[2] As far as concern of India at present it's a upcoming problem and so it need attention. However, with the increasing median age of the population and weakening root of family values bringing a hazy future for those who are to be become aged in coming days.

\section{PROBLEM DEFINATION}

With 1.21 million population or nearly 16 per cent of the world's population, India is a vary large country. The country with 3.28 million sq. km. of geographical area has very much in the physical, social, cultural, economic and demographic attributes. With the development in the different sectors as well as in the demographic sector also change in competitive way. For example, there are vast differences in the quantity and quality of the elderly population along with their living arrangement. It is estimated that the Indian aged population is currently the second largest in the world. If the trend continues, the absolute number of the over 60 population in India will reach the level of 137 million by 2021 from 76 million in 2001.[2] Now a day the rate of the elderly population growth is $10 \%$.

The north eastern part of India Assam, which concentrate about 31 million (2011)population over an area 78523 sq. km. The density of population is 397 and sex ratio is 954 . Here the aged population increased in a venerable way only because of the increased in medical facilities, life expectancy, birth and decreased in death rate etc. The increase in aged population good direction to the society but their life style is becomes very bed in somewhere and they spent a very dirty life. So I make a field report on the aged people of Jorhat which is becoming a serious issue for the society of Jorhat.

\section{OBJECTIVES}

Every Geographical study gas some objectives. Hence we also selected some objectives to conduct our survey and analysis the data thoroughly. Our objectives of the study are :-

i. To highlight the status of aged people in our society special reference to Jorhat

ii. To highlight the life style of the aged people .

iii. To make attention on weather ageing is a problem or not in our society.

\section{METHODOLOGY}

Collection of the is the prime concern in the research methodology. Like that of way first of all to fill our requirement we collect necessarily data from Secondary source like Books, Journals and Internet.

In conducting the survey we used survey schedules and purposive sampling method on our project. But due to the shortage of time we could only conduct our survey in 55 persons. We have collected primary data through schedule by door to door survey of 55 family. On doing the work we used purposive sampling method, because in purposive sampling, the selection of the units is done for purpose.

After receiving the data we processed and coded it and transferred to a master table and than represented through statistical and cartographic techniques. By analyzing the data the report is drafted containing the findings of the survey. In the introduction part we use internet, books, journal etc. and the analysis part purely primary data base.

\section{ANALYSIS}

PHYSIOGRAPHY OF JORHAT:_Jorhat district is located on the south bank of the river Brahmaputra, covering an area of $2859 \mathrm{sq} \mathrm{km}$. in lies by the state of National Highway No 37 at a distance of $314 \mathrm{~km}$ to the North East Guwahati and 134 to South West Dibrugarh. It lies between $26^{\circ} 45^{\prime} \mathrm{N}$ to $94^{\circ} 13^{\prime} \mathrm{E}$ and $26^{\circ} 75^{\prime} \mathrm{N}$ to $94^{\circ} 22^{\prime} \mathrm{E}$ latitude. Jorhat share its border with Luhitsuti, North Lakhimpur on North, in the East North Naga Hills on the Sivasagar and with Golaghat district in the west. On the basis of the 2011, the district has two towns, 6 urban areas, 792 village, 6 Development Blocks and 3 subdivisions.[3]

With the acceptations of some undulating surface feature in the extream southern parts, the entire district is relatively plain with attitude varying from $150 \mathrm{mt}$ $200 \mathrm{mts}$.in the southern parts and 50 to $60 \mathrm{mts}$. In the North. On the basis of local geographical features and 


\section{SJIF Impact Factor: 7.001| ISI I.F.Value:1.241| Journal DOI: 10.36713/epra2016 \\ ISSN: 2455-7838(Online) \\ EPRA International Journal of Research and Development (IJRD) \\ Volume: 5 | Issue: 7 | July 2020 \\ - Peer Reviewed Journal}

active geomorphologic process the district can be divided into the following there sub-divisions.

1.Northern low laying areas

2.Central fertile plains and

3.Southern highlands

District Jorhat is drained by the river Brahmaputra and its tributaries viz. Jhanji,Bhogdoi and Kakodunga which originate from Naga hills in the South. All these tributaries meet the highly river Brahmaputra which cross the district from East to West.

Jorhat district is characterized by high humid atmosphere, abundant rains and general coolness. Four reasons are general prevalentin this district with high differences in weather conditions. These are as follows

i. The cold seasons December to February

iiThe seasons of serve thunderstorms March to May

iii.The south west Monsoon June to the beginning of October

iv. The pest monsoon October to November

Temporal variations in the distribution of precipitation, temperature, humidity and evatranspiration are the main distinguished feature of these seasons

The average annual rainfall in the district is $2000 \mathrm{~mm}$. about $67 \%$ of the annual rainfall in the district is receive during the monsoon from June to October. July being the month with the maximum rainfall.

POPULATION : Jorhat, a district of Assam in 2011, Jorhat had population of 1,091,295 of which male and female were 557,944 and 533,351 respectively. Jorhat District recorded increase of 14.69 percent to its population compared to 1991. The initial provisional data suggest a density of 383 in 2011 compared to 350 of 2001. Total area under Jorhat district is of about 2,851 sq.km. Average literacy rate of Jorhat in 2011 were 83.42 compared to 76.34 of 2001 . If things are looked out at gender wise, male and female literacy were 88.38 and 78.22 respectively. [4]

In this district the proportion of the aged population is also increased in a significant way, because the life expectancy of the people is also increased.

\section{INFORMATION ABOUT THE AGED PERSONS}

The age of 60 or 65 , roughly equivalent to retirement ages in most developed countries, is said to be the beginning of old age. In many parts of the developing world, chronological time has little or no importance in the meaning of old age. But now a day very important to know what is the meaning of old age or aged and their related problems. So when we student of Population geography study about the aged people we are trying to study the old man and the problems related to him and his life style also. In survey time we find different type of people of different cast, different religion etc.

SEX RATIO: Numerical measurement of male and female of an given population is termed as Sex Ratio. It has been calculated differently in different countries of the world. In India it is expressed as the number of females per thousand male. The sex ratio of Jorhat is 903.Among the surveyed people we find 56\% male and $44 \%$ female aged persons of different ages. The sex ratio is shown here with the following diagram.

Table- 1

\begin{tabular}{|c|c|c|}
\hline \multicolumn{3}{|c|}{ PERCENTAGE OF SEXWISE AGED POPULATION } \\
\hline Sex & $\begin{array}{c}\text { no of aged } \\
\text { persons }\end{array}$ & $\begin{array}{c}\text { \% of the aged } \\
\text { person }\end{array}$ \\
\hline Male & 31 & 56 \\
\hline Female & 24 & 44 \\
\hline
\end{tabular}




\section{EPRA International Journal of Research and Development (IJRD)}

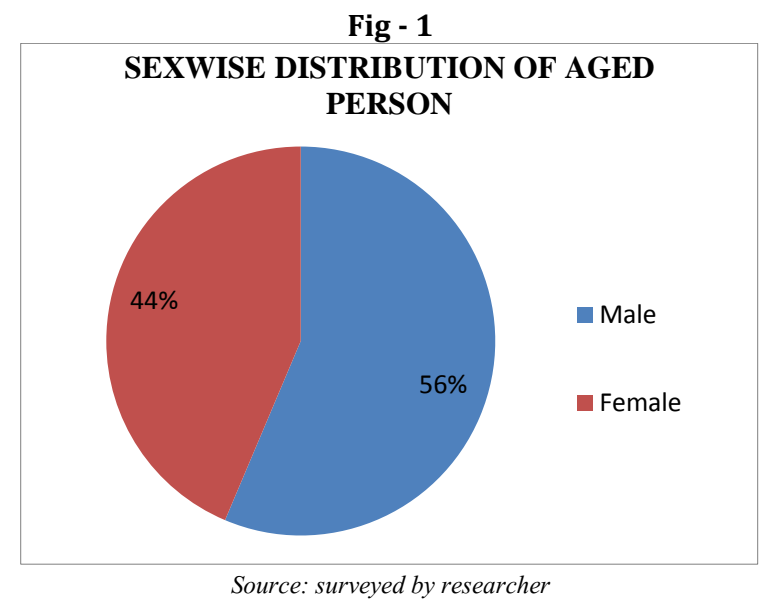

RELIGION, CAST AND COMMUNITY : In case of religion and cast in our survey area Jorhat maximum people belongs to Hindu religion and second religion belongs to Muslim and other religions in this area is very rare and so we have not find any other religious person in our survey. Out of the surveyed persons about $58 \%$ Hindu and $42 \%$ peoples belongs to Muslim which is shown by the following table and diagram.

Table - 2

\begin{tabular}{|c|c|c|}
\hline \multicolumn{3}{|c|}{ PERCENTAGE OF THE AGED PERSONS RELIGION } \\
\hline RELIGION & TOTAL NO & \% OF THE NO \\
\hline Hindu & 32 & 58 \\
\hline Muslim & 23 & 42 \\
\hline Christian & 0 & 0 \\
\hline Others & 0 & 0 \\
\hline
\end{tabular}

Fig - 2

PERCENTAGE OF AGED PEOPLES RELIGON

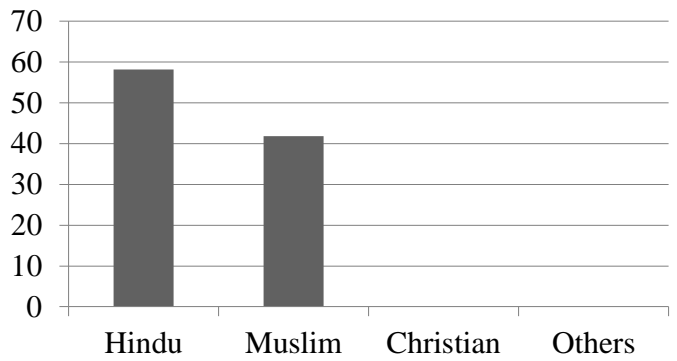

But similarly if we consider the cast of the aged persons of the surveyed area maximum population belongs to the General cast which is about $58 \%$ and
$40 \%$ of the $\mathrm{OBC}$ and only $2 \%$ people are belongs to the ST cast out of the total 55 surveyed peoples. 
Table - 3

\begin{tabular}{|c|c|c|}
\hline \multicolumn{3}{|c|}{ PERCENTAGE OF CAST OF AGED PERSON } \\
\hline Cast & Total no & \% of cast of the aged person \\
\hline GEN & 32 & 58 \\
\hline ST & 0 & 0 \\
\hline SC & 1 & 2 \\
\hline OBC & 22 & 40 \\
\hline Others & 0 & 0 \\
\hline
\end{tabular}

Fig- 3

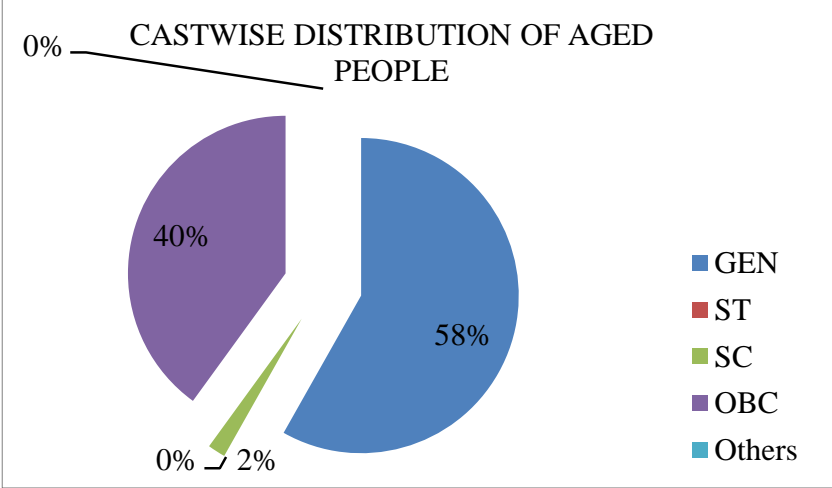

Source: surveyed by researcher

The above casts are not only belongs to the Assamese community, but they are belongs from the different communities. The following tables and diagrams represent the peoples of the different casts and communities.

Table -4

\begin{tabular}{|c|c|c|}
\hline \multicolumn{3}{|c|}{ COMMUNITYWISE DISTRIBUTION OF THE AGED PERSONS } \\
\hline COMMUNITY & TOTAL NO & \% OF THE NO \\
\hline Assamese & 23 & 42 \\
\hline Muslim & 23 & 42 \\
\hline Bengali & 8 & 15 \\
\hline Others & 1 & 1 \\
\hline
\end{tabular}




\section{EPRA International Journal of Research and Development (IJRD)}

Fig -4

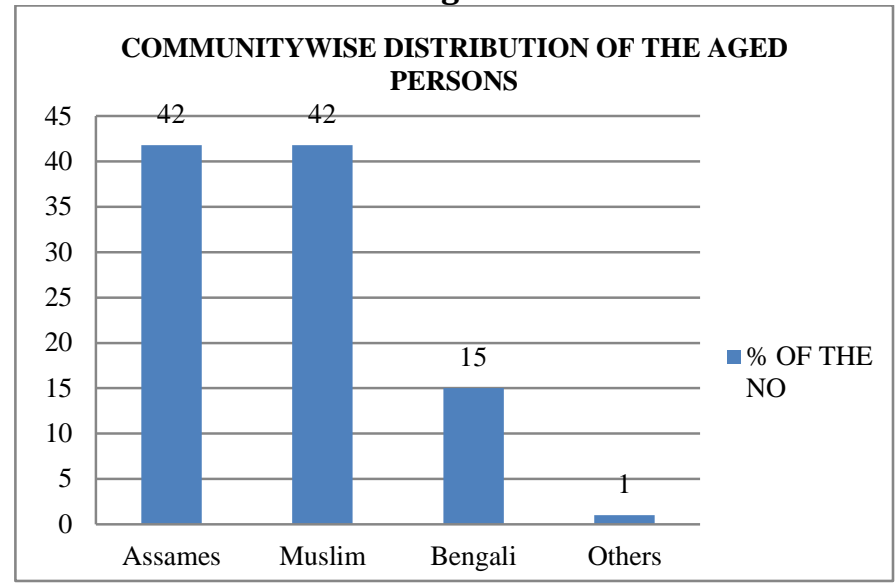

Source: surveyed by researcher

\section{AGE COMPOSITION:}

Age means the estimated or calculated interval of time between the date of birth and the date of census, expressed in completed solar year.

The population may be divided into sub-groups on the basis of age such as $0-5,6-16,17-24,25-60$ and $>60$ etc. The distribution of population in different age group is called age composition. For the academic purpose scholar, researcher and students has many scope to know age composition which is given below......

For making elaborate study and composition.
To make inventories of human resources and planning. For examining social and economic structure.

To know the changing structure

This paper considered only the aged peoples or the age group of above 60 . Here in our surveyed area maximum aged people belongs to 60-65 age group whereas only 3 are in between 90 to 100 where 1 in $90-95,1$ in $95-100$ and 1 in above 100 .

Table- 5

\begin{tabular}{|c|c|c|}
\hline \multicolumn{3}{|c|}{ AGE DISTRIBUTION OF THE AGED PERSONS } \\
\hline Age Structure & TOTAL NO & $\begin{array}{c}\text { \% OF THE } \\
\text { NO }\end{array}$ \\
\hline $60-65$ & 22 & 40 \\
\hline $65-70$ & 7 & 13 \\
\hline $70-75$ & 12 & 22 \\
\hline $75-80$ & 5 & 9 \\
\hline $80-85$ & 4 & 7 \\
\hline $85-90$ & 2 & 4 \\
\hline $90-95$ & 1 & 2 \\
\hline $95-100$ & 1 & 2 \\
\hline $100+$ & 1 & 2 \\
\hline
\end{tabular}




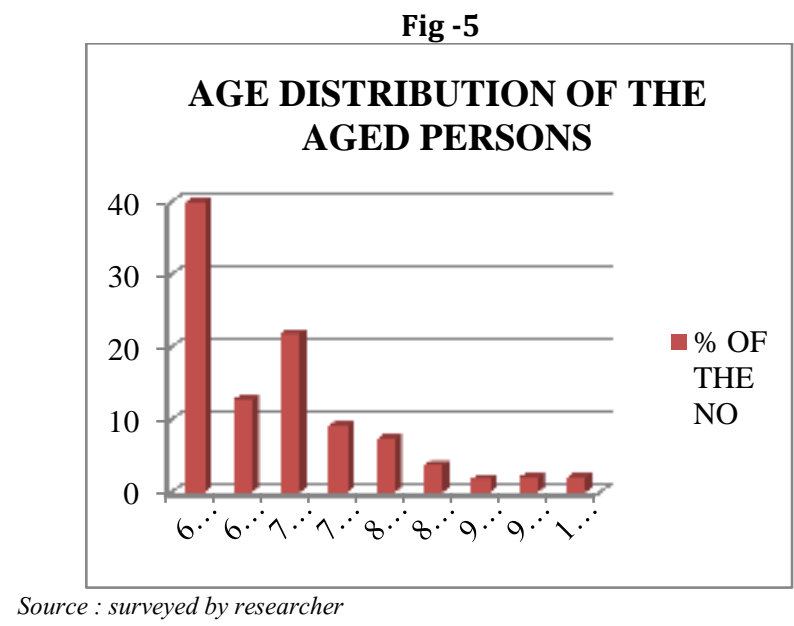

\section{EDUCATION STRUCTURE:}

The concept of literacy varies from country to country. In India the person who can read and write to termed as literate. It is an important indicator of socio-cultural development and political consciousness. In fact it is a vehicle of socio-economic transformation as it facilitates the acquisition of specific skills and occupational competence and accelerates the process of social change. In the surveyed area most of the aged persons are literate. But, out of them many persons are below H.S.L.C. level(25)and 4 persons are HSLC, H.S.pass(5),only 7 are graduate ,2 are PG and only 3 persons possesses other technical education .

Table -6

\begin{tabular}{|c|c|}
\hline \multicolumn{2}{|c|}{ TABLE FOR EDUCATIONAL QUALIFICATION } \\
\hline Education Qualification & Quantity \\
\hline Illiterate & 9 \\
\hline <HSLC & 25 \\
\hline HSLC & 4 \\
\hline HSSLC & 5 \\
\hline Graduate & 7 \\
\hline PG & 2 \\
\hline Others & 3 \\
\hline
\end{tabular}

Fig - 6

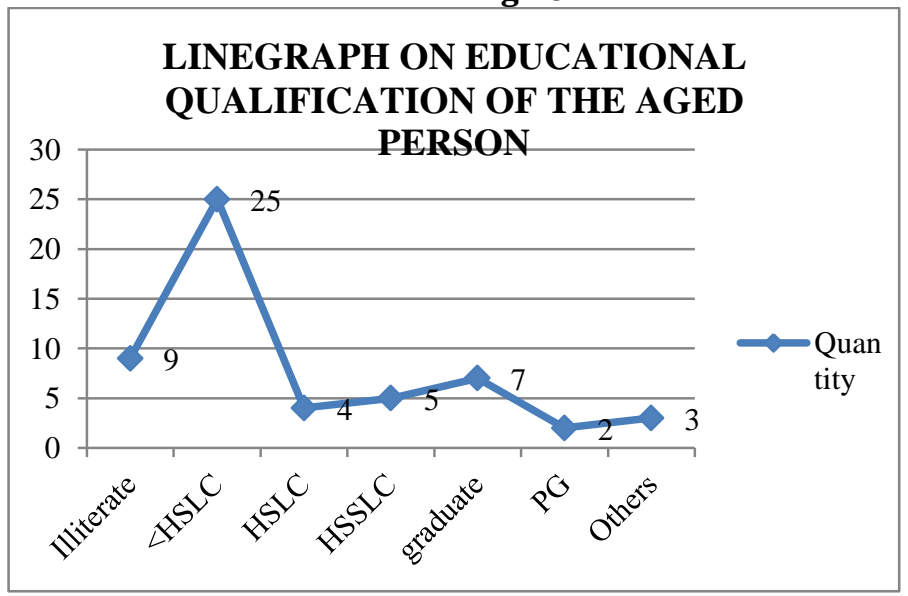

Source: surveyed by researcher 


\section{EPRA International Journal of Research and Development (IJRD)

\section{ECONOMIC STRUCTURE :}

OCCUPATION STRUCTURE : Occupation is the primary form of activity which is curved out every person in a society. The occupational pattern of the people are classified into two categories. They are respectively primary and secondary. The aged person occupation is slightly different from others. They are not fit for every purpose. The aged persons occupation are viz. as service, business, cultivation and pension and others. Most of the persons in the surveyed area almost $78 \%$ dependent upon on the off springs and a few of them do their service (16\%) and business(4\%) and other $2 \%$ is engaged in cultivation.

Table -7

\begin{tabular}{|c|c|c|}
\hline occupation & Quantity & percentage of the no \\
\hline Service & 9 & 16 \\
\hline Business & 2 & 4 \\
\hline Cultivation & 1 & 2 \\
\hline Other/Pension & 43 & 78 \\
\hline
\end{tabular}

Fig-7

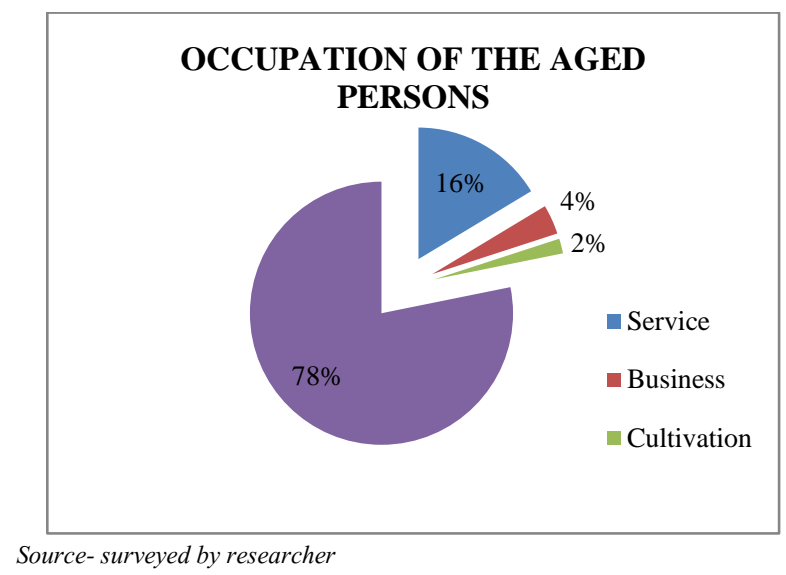

INCOME:Income determines the standard of living of a person in a society. Among the aged person according to their occupation they earn differently in different time. Sometimes in our society aged persons earn more than a active person but sometimes old persons totally dependent upon their off springs. When they dependent upon the others some of the off springs treated him differently. So we the student of population geography trying to study about it but we got there most of the aged persons in our surveyed area totally dependent upon self. The following table and diagram represents the monthly income of the aged persons.

Table - 8

\begin{tabular}{|c|c|}
\hline MONTHLY INCOME OF THE AGED PERSONS \\
\hline RANGE & TOTAL NO \\
\hline$<1000$ & 2 \\
\hline $1000-5000$ & 19 \\
\hline $5000-10000$ & 12 \\
\hline $10000-15000$ & 4 \\
\hline $15000>$ & 18 \\
\hline
\end{tabular}




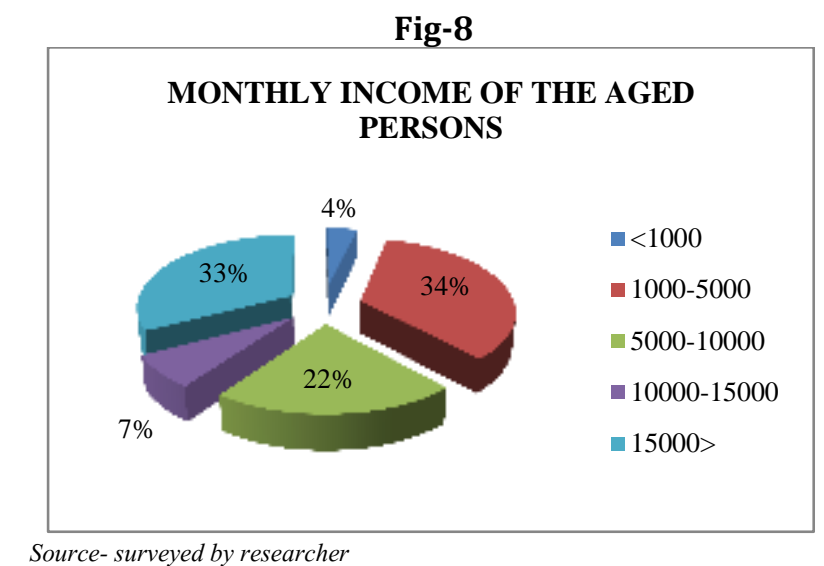

BANK ACCOUNT : Bank account of a man is a economic standard of man in our society. Among the aged persons is not popular in the rural areas. But in our surveyed area most of the persons have their account such as 37 persons have their bank account in running conditions out of 55 persons. So it is very good significant to our society.

Table 9

\begin{tabular}{|l|l|}
\hline \multicolumn{2}{|c|}{ Bank AC } \\
\hline Responds & Total no \\
\hline Yes & 37 \\
\hline No & 18 \\
\hline
\end{tabular}

Fig-9

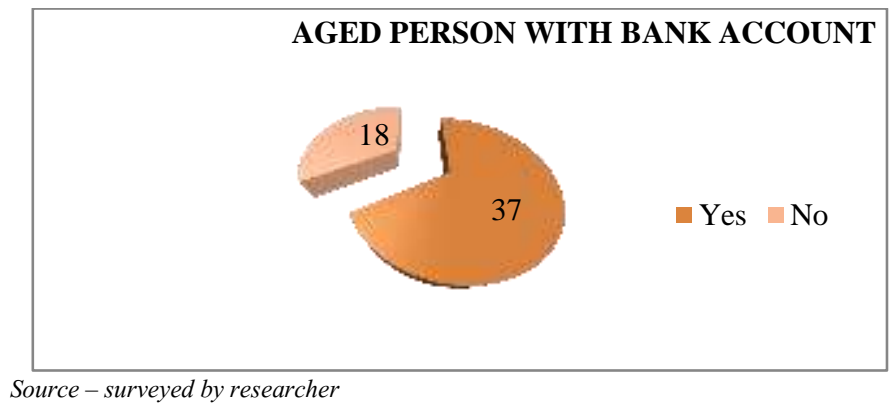

USE OF ATM :Whenever the bank account is most popular among the aged persons but they don't interested to use ATM as compared to the other persons in our society.
Most of the aged persons interested to withdrawal their case in mandatory process.

The following tables and diagrams represent the bank accounts and use of ATM by the aged persons.

Table - 10

\begin{tabular}{|c|c|}
\hline \multicolumn{2}{|c|}{ Use of ATM } \\
\hline RESPONDSE & $\begin{array}{l}\text { TOTAL NO } \\
\text { RESPONDS }\end{array}$ \\
\hline YES & 11 \\
\hline NO & 26 \\
\hline
\end{tabular}




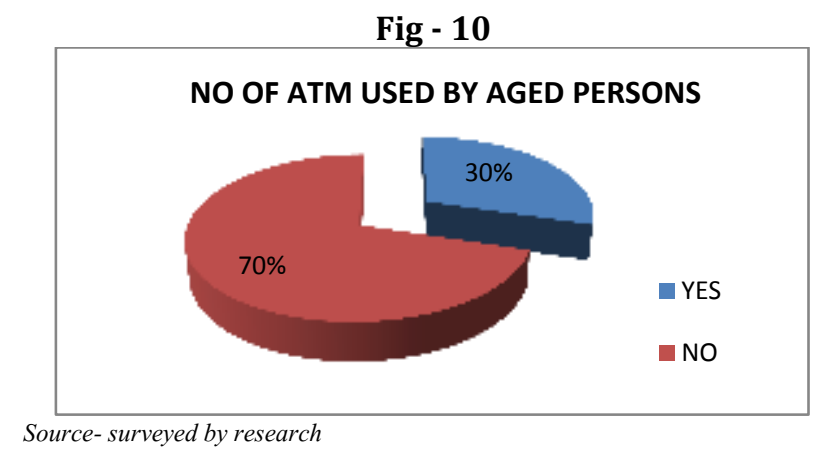

INSURANCE POLICIES:Insurance policies are not popular among the aged persons. So only a few persons have insurance policies in old age. Because they don't need insurance policies in this stage, they want to enjoy themselves. So, in observed area we found only a few aged persons with insurance policy.

Table - 11

\begin{tabular}{|c|c|}
\hline \multicolumn{2}{|c|}{ TABLE FOR INSURANCE POLICIES } \\
\hline RESPONS & NO OF RESPONSE \\
\hline HAVE & 16 \\
\hline HAVENOT & 39 \\
\hline
\end{tabular}

Fig -11

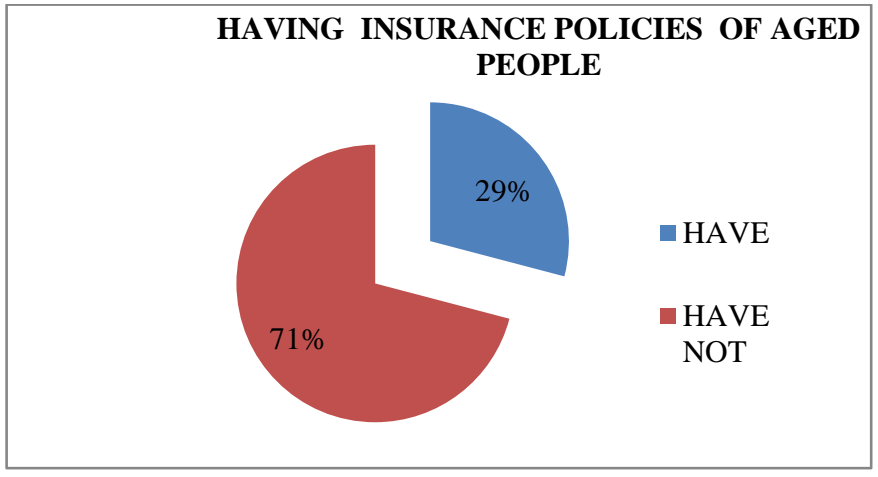

Source - surveyed by researcher

FIX DEPOSIT : As like as the insurance policies aged persons don't need FD . correspondingly, we found only a persons with FD in our surveyed area.

\section{HEALTH STATUS}

EATING HABIT :Eating habit means the foods which a person like to eat. Whenever he is vegetarian or non vegetarian. In our surveyed area we found 52 persons are non vegetarian and only 3 persons are vegetarian among the aged persons.

Table -12

\begin{tabular}{|c|c|}
\hline \multicolumn{2}{|c|}{ Eating. Habit } \\
\hline Veg & 3 \\
\hline Non-veg & 52 \\
\hline
\end{tabular}




\section{EPRA International Journal of Research and Development (IJRD)

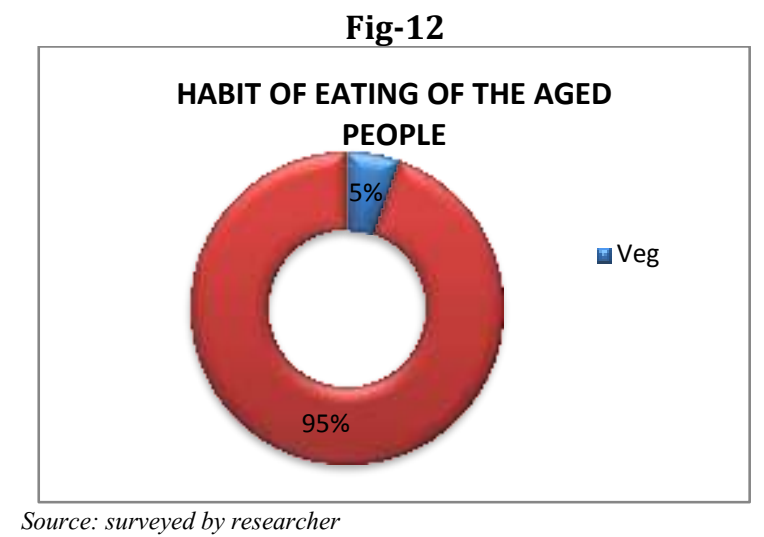

In other eating habit of the aged persons like smoking, liquor, beetle nut etc. we found 35 persons eating beetle nut, tobacco and others and other 9 persons smokes nad 6 persons take liquor. This represents that most of the aged persons eat beetle nut ,tobacco and others and only a few persons take liquor and smoke in their old age. The following diagram represents the different eating habit of the aged persons.

Whether the aged person is veg. or non veg., most of the aged persons food are provided by their wives or daughter in low. They are also take cared by their wives and their daughter in lows.

Table -13

\begin{tabular}{|c|c|}
\hline \multicolumn{2}{|c|}{ Table for Other Eating Habits of the Ageds } \\
\hline Smoking & 9 \\
\hline Liquor & 6 \\
\hline Others & 35 \\
\hline
\end{tabular}

Fig-13

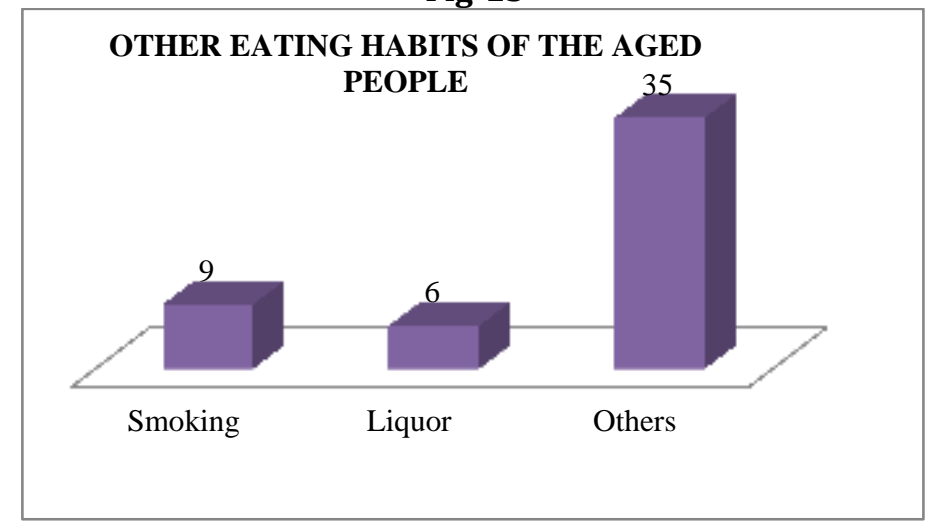

Source : surveyed by researcher

DISEASES:Diseases are those which becomes a person too weak. In old age this diseases attack very much. According to our survey it is clearly come out that most of the aged persons in our society are suffering from different diseases such as BP, Joint Pain, Weak Eye sight, Sugar, respiratory etc. In our surveyed area out 55 persons 33 persons suffering from weak eye sight, 30 persons suffering from BP and 26 persons suffering from joint pain. So, from our collected data it is clear that some aged persons auffering from all types of diseases, some are two or three etc.

Whether they suffering or not but from our survey we find out that most of the aged persons get their regular medical facilities which is a very good sign for our society. 
Table- 14

\begin{tabular}{|l|l|c|}
\hline \multicolumn{3}{|c|}{ TABLE FOR MEDICAL FREQUENCY } \\
\hline FREQUENCY & IN NO & \% OF THE FREQUENCY \\
\hline REGULAR & 49 & 89 \\
\hline IRREGULAR & 6 & 11 \\
\hline
\end{tabular}

Fig - 14

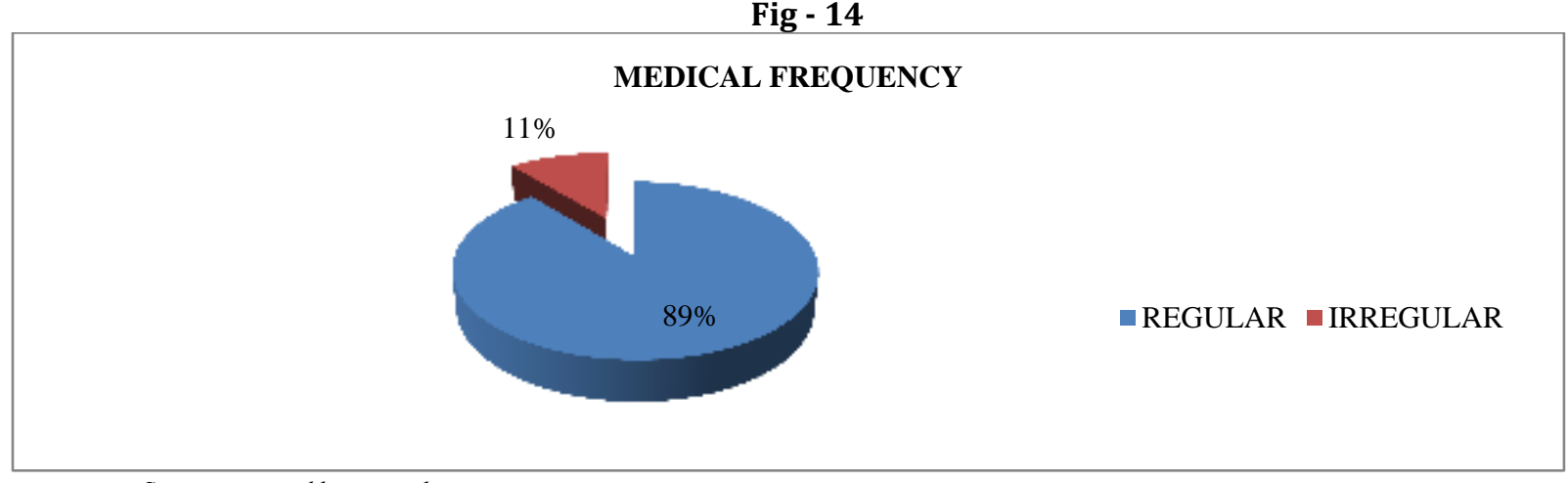

Source: surveyed by researcher

SANITATION:The aged persons of a society mainly depend upon others. So, they always need some good sanitation facility through which they live self dependently. The facilities which are needed by a aged person such as pacca latrine (Attached) with hot water facilities.
In the surveyed area somewhere this facilities are available but everybody don't get such facilities of sanitation, so they face various problems. The following tables \& diagrams represent the sanitation facilities of the aged persons of Jorhat.

Table -15

\begin{tabular}{|c|c|c|}
\hline & \multicolumn{2}{|c|}{ TABLE FOR SANITATION } \\
\hline LATRIN & USE IN NO & PERCENTAGE OF NO \\
\hline Pacca & 40 & 73 \\
\hline Kutcha & 11 & 20 \\
\hline $\begin{array}{c}\text { opn } \\
\text { Spce }\end{array}$ & 4 & 7 \\
\hline
\end{tabular}

Fig - 15

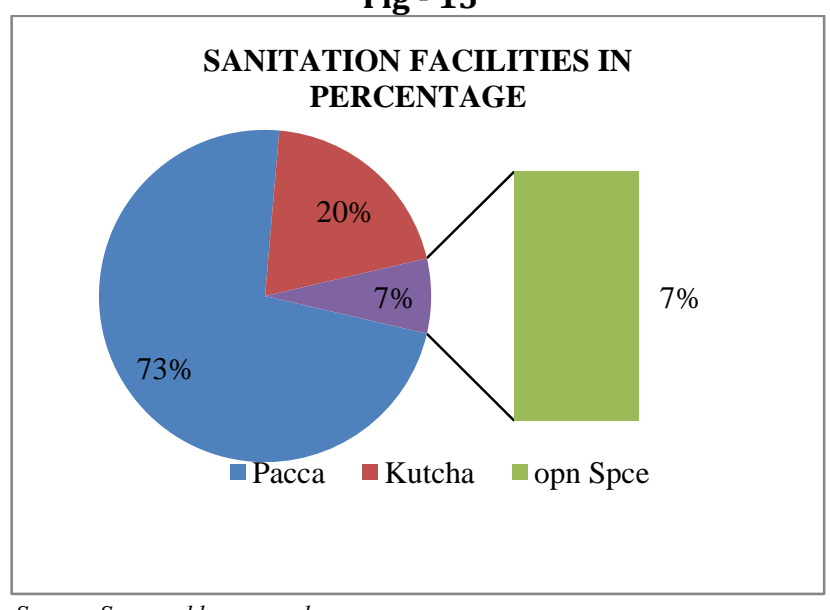

Source: Surveyed by researcher 


\section{EPRA International Journal of Research and Development (IJRD) \\ Volume: 5 | Issue: 7 | July 2020 \\ - Peer Reviewed Journal}

FAMILY STRUCTURE:To study about any person, it is very essential to know about the family. In our surveyed area we have found 50 out of 55 aged persons living with their family \& only 5 persons live alone. It indicates that in our society or the society of the surveyed area accompanied the aged persons. Means the aged persons of our society do not face any problem from their families. But sometimes, it's not possible in joint families so, out of our surveyed persons about 34 persons live in nuclear family. Only 21 persons live jointly. These are shown by the following Table \& diagrams

Table- 16

\begin{tabular}{|c|c|c|}
\hline \multicolumn{3}{|c|}{ Living With Family } \\
\hline RESPONSE & NO & \% OF THE RESPONSE \\
\hline YES & 50 & 91 \\
\hline NO & 5 & 9 \\
\hline
\end{tabular}

Fig - 16

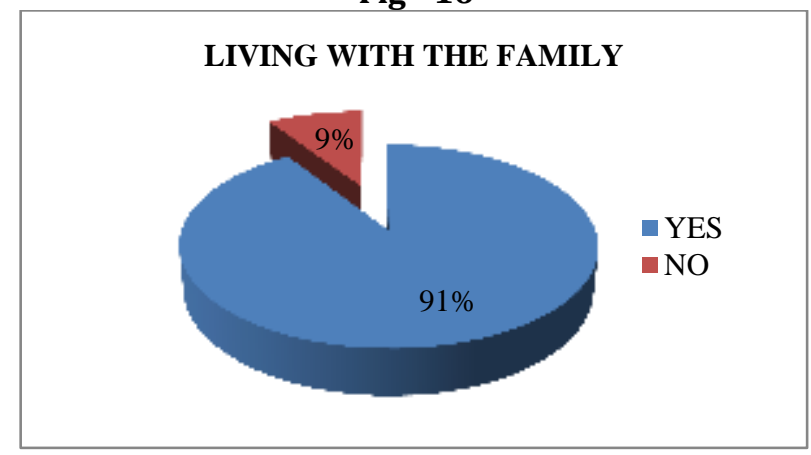

Source: surveyed by researcher

If we consider the aged person \& ask them whether they are migrated or not, most of them reply no means they are permanent inhabitants. They are residing in their present address for almost 60-80 years.(20 persons) Other 35 persons, 12 are lived in their address below 20 years $\& 23$ persons are staying there for $20-40$ years.

In case of migration, migrated aged person's percentage is comparatively low in Jorhat which is 18 persons out of 55. These migrated persons came to their address for various purposes e.g.- 7 for job, 3 for business, 1 for clash \& other 7 for different reasons.Most of these aged persons families are nuclear \& they have one or two children also living with them.

Table-17

\begin{tabular}{|c|c|c|}
\hline \multicolumn{3}{|c|}{ PERCENTAGE OF THE MIGRATED AGED POPULATION } \\
\hline Responds & Migrated population & $\begin{array}{c}\text { \% of the migrated } \\
\text { population }\end{array}$ \\
\hline Yes & 18 & 33 \\
\hline No & 37 & 67 \\
\hline
\end{tabular}


Fig - 17

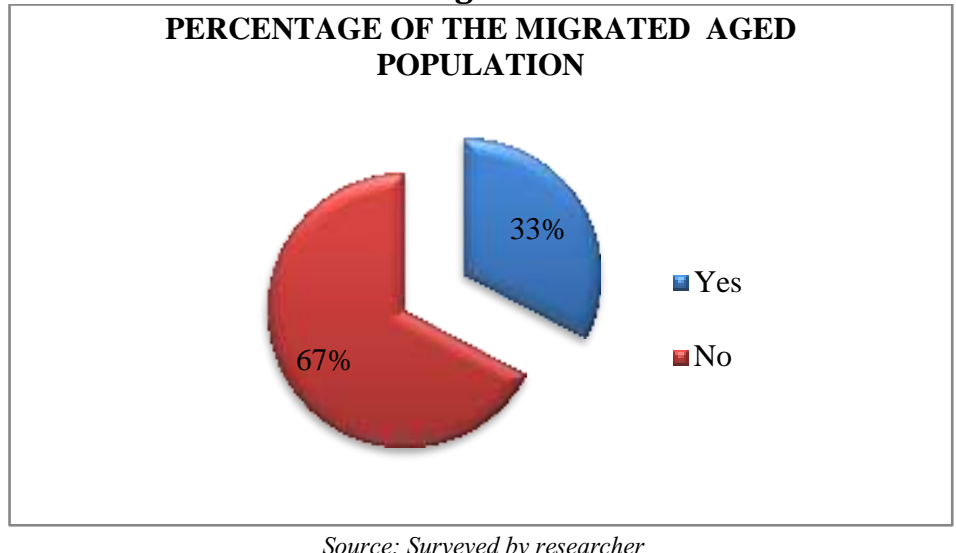

The aged persons of our surveyed area most of them enjoy life with families in their own houses.

Table-18

\begin{tabular}{|c|c|c|}
\hline OWNERSHIP & NOS & \% OF THE NOS \\
\hline Own & 50 & 91 \\
\hline Rented & 2 & 4 \\
\hline Govt & 2 & 4 \\
\hline Others & 1 & 2 \\
\hline
\end{tabular}

Fig - 18

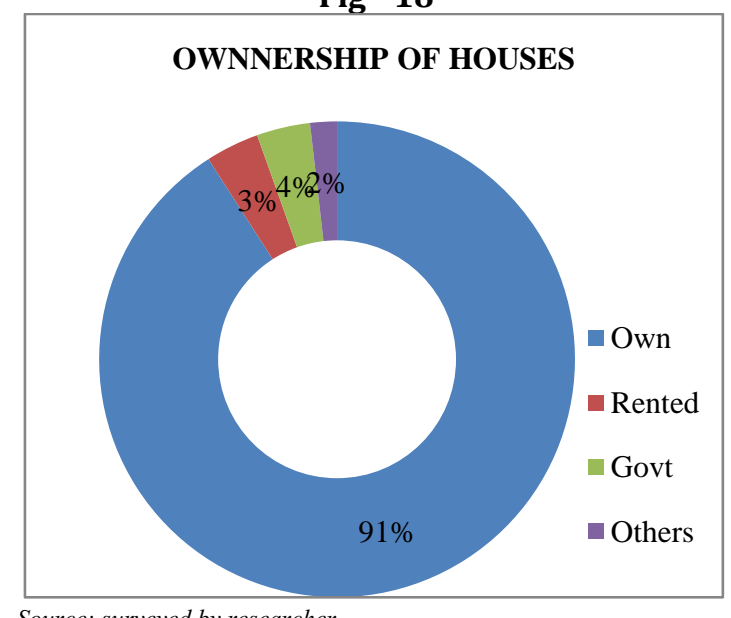

Source: surveyed by researcher

From the previous table, we found that out of 55 persons, 50 of them have their own house, 2 lives in rented house, 2 of them live in govt. provided house \& 1 of is gypsy.Consideration of the type of houses of the aged persons we found that about $57 \%$ out of 55 persons live in pacca houses, $27 \%$ live in semi pacca houses and only $16 \%$ live in kutcha houses. This house types of the aged persons indicate that their socio economic condition is comparatively higher than the people of rural areas. 
Table -19

\begin{tabular}{|l|c|c|}
\hline \multicolumn{2}{|c|}{ TYPES OF THE HOUSES OF THE AGED PEOPLE } \\
\hline House. Type & $\begin{array}{c}\text { NO OF PERSON } \\
\text { LIVE }\end{array}$ & \% OF THE NOS \\
\hline Kacha & 15 & 27 \\
\hline Semi pacca & 9 & 16 \\
\hline Pacca & 31 & 57 \\
\hline
\end{tabular}

Fig - 19

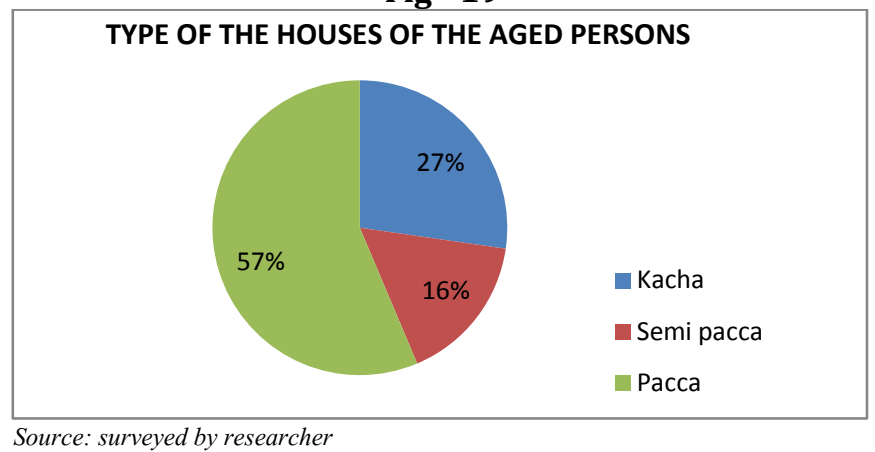

If we consider whether the aged persons are living freely with their family or not then it is absolutely right, they live with their family as they wish \& interact with the outsiders. Only a few of them are suffering from family violence \& live without interacting with others. The following table \& diagrams shows the above mentioned data.

Table-20

\begin{tabular}{|c|c|c|}
\hline \multicolumn{3}{|c|}{ Table for interaction of the aged person with outsiders } \\
\hline Response & In Nos & Percentage of the nos \\
\hline Yes & 48 & 87 \\
\hline No & 7 & 13 \\
\hline
\end{tabular}

Fig - 20

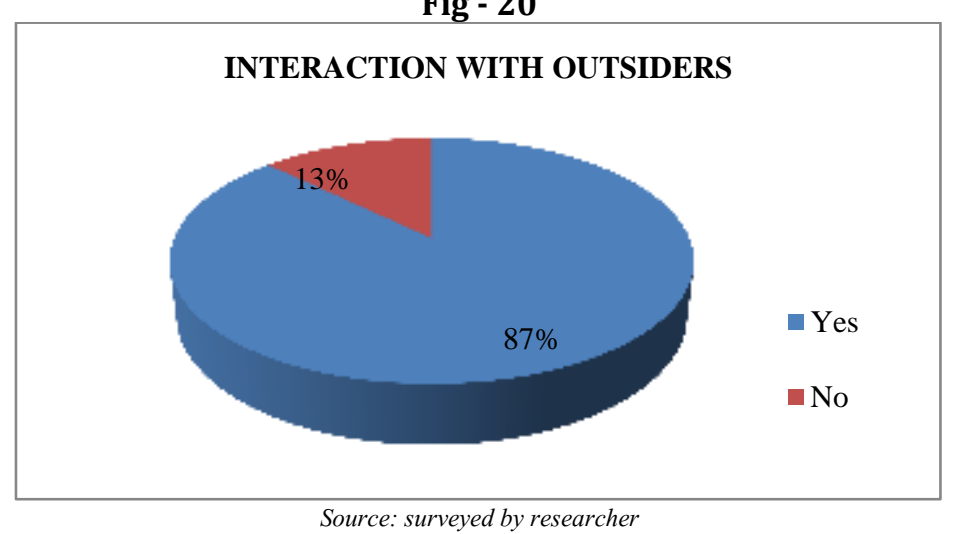




\section{EPRA International Journal of Research and Development (IJRD)

Table-21

\begin{tabular}{|c|c|c|}
\hline \multicolumn{2}{|c|}{ Table for suffering from the family Violence } \\
\hline Response & $\begin{array}{c}\text { total in } \\
\text { no }\end{array}$ & Percentage of the no \\
\hline Yes & 6 & 11 \\
\hline No & 49 & 89 \\
\hline
\end{tabular}

Fig - 21

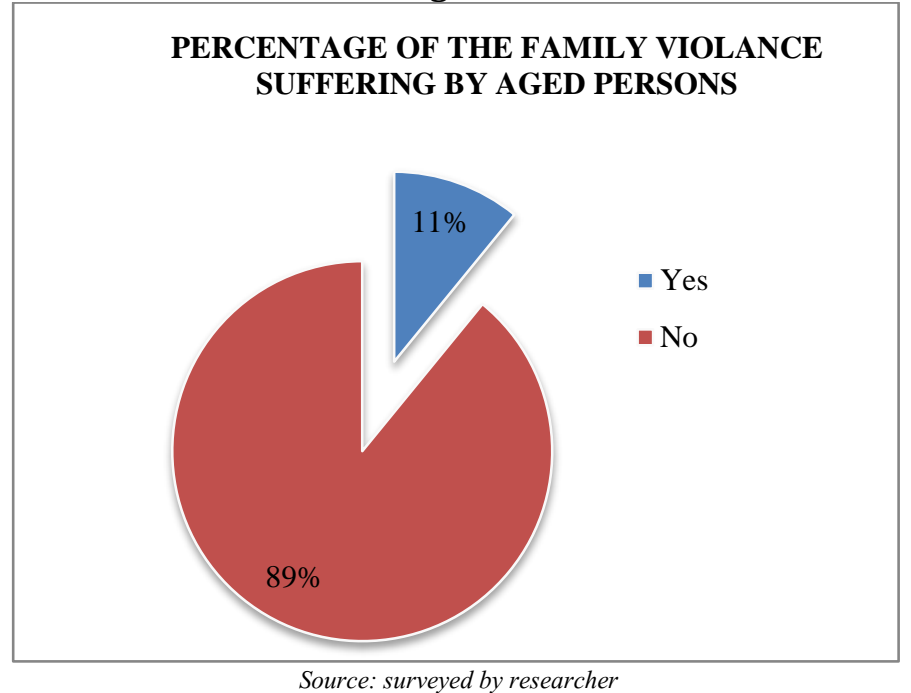

\section{FINDINGS}

1. Sex ratio of the aged persons is $56: 44$, where $56 \%$ male and $44 \%$ female.

2. Percentage of the religion most of the aged persons belongs to Hindu(58\%), Muslim (42\%), and others $0 \%$.among this religion $58 \%$ belongs to General, $40 \%$ OBC, and only $2 \%$ belongs to SC population.

3. Most of the aged persons belongs to 60 to 65 age group.

4. In case of educational qualification maximum aged people belongs to below $\operatorname{HSLC}(25)$, illiterate (9), HSLC (4), HSSLC (5), graduate (7),PG (2) and others (3).

5. Most of the aged persons have their own property and they earn their money from pensions or other sources e.g. dependent upon others which is a bed significant to our society.

6. Most of the aged persons have their own bank account but they are not interested to use ATMs.

7. There have not more insurance policies and FD among the aged persons.

8. Among the aged persons most of them are non veg and but only a few persons are interested in smoking, taking drink etc.

9. The health of the aged persons are physically weak and suffered by different diseases. But it is very good sign that they take regular medical facilities it almost $89 \%$.

10. Most of the aged persons get pacca sanitation facilities but they don't get as they wish.

11. Only a few persons migrated to this area and most of them permanently resided.

12. The aged persons who were migrated to our surveyed area for different purpose such as job, business, clash etc.

13. Family structure of the aged persons significantly nuclear and most of them live with their family.

14. Only a few aged persons of our society suffering from family violence and don't interact with out sidders.

\section{PROBLEMS}

1. Literacy problem, most of the aged persons are not highly educated they are just know to read and write.

2. Most of the aged persons depended upon the off springs.

3. Among the aged persons most persons are not get adequate sanitation facilities like pacca and attached latrine, available hot water facilities.

4. Some of the aged persons suffering from family violence. 
5. Aged persons are suffering from different diseases.

\section{SOLUTION}

1. Improve the education system

2. Provide old age pension to the old persons

3. Improve hospital facilities

4. Provide act against the family violence suffering by aged persons.

\section{CONCLUSION}

After analyzing the life style of the aged persons we found that in our society the aged persons are the person who is physically and socially called as the old person above the age 60. The aged persons in our society is not a problem but it is a becoming as a problem for us. Because when the percentage of the aged persons increases the dependency ratio is also increases. So the government has to take the step to control this problem.

\section{REFERENCE}

1. Ministry of Health govt of UAE, www.moh.sa, retrived in Nov 2019

2. Mohantty Anuradha,(2002), 'Population Aging in India and the effectiveness of social assistance programme in Orissa- a human right perspective',Second World Assembly On Aging, Spain, $8^{\text {th }}$ to $12^{\text {th }}$ April,PECUC, Orissa,p 1- 16

3. Geography of Jorhat, www.wikipedia.org, retruved in $2^{\text {nd }}$ May, 2020

4. Census of india- household with aged persons, www.censusofindia.govt.in retrived on $24^{\text {th }}$ March, 2020

5. Chandana RC,(2009), Geography Of Population, chapter 8 , edition $8^{\text {th }}$, kalyani publication. 